Nig. J. Biotech. Vol. 38 (2) : 1-13 (Dec 2021)

ISSN: 01891731

Available online at

http://www.ajol.info/index.php/njb/index

and www.biotechsocietynigeria.org

DOI: https://dx.doi.org/10.4314/njb.v38i2.1

\title{
Effects of light intensity and photoperiod on growth, lipid accumulation and fatty acid composition of Desmodesmus subspicatus LC172266 under photoautotrophic cultivation
}

\author{
I. O. Ogbonna ${ }^{1 *}$, J. Ikwebe ${ }^{2}$, J. C. Ogbonna ${ }^{3}$, C. N. Eze ${ }^{4}$, J. B. \\ Ndrimbula5
}

\author{
${ }^{1}$ Department of Microbiology, College of Science, Federal University of Agriculture, Makurdi, \\ PMB 2373, Nigeria \\ 2 Department of Biochemistry, Federal University Wukari, 200 K/Ala Road, P.M.B 1020, Wukari, \\ Taraba State, Nigeria \\ 3 Department of Microbiology, University of Nigeria, Nsukka, Enugu State, Nigeria \\ ${ }^{4}$ Department of Science Laboratory Technology, University of Nigeria, Nsukka, Enugu State, \\ Nigeria \\ 5 Department of Crop Protection, University of Maiduguri, Borno State, Nigeria
}

\begin{abstract}
Microalgae oil accumulation in their natural growing states hardly reaches the quantities needed to replace fossil-derived diesel. Therefore, for algae to be used as biofuel feedstock, their growths are manipulated with the aim of achieving high cell density and high lipid accumulation. Two major factors affecting microalgal biomass and lipid productivity are light intensity and photoperiod. In the present study, Desmodesmus subspicatus was grown photoautotrophically under varying light intensities and photoperiods with a view to assessing the growth, lipid accumulation potential and fatty acid composition. Whereas the optimal light intensity for biomass production of the microalga was $5000 \mathrm{~lx}$, that for lipid productivity was $3500 \mathrm{~lx}$. At $5000 \mathrm{~lx}$ and 18: $6 \mathrm{~h}$ light/dark cycle, biomass yield, lipid content and lipid productivity were highest, at values of $1.92 \pm 0.03 \mathrm{~g} / \mathrm{L}, 53 \%$ and $118.80 \pm 2.04 \mathrm{mgL}^{-1} \mathrm{day}^{-1}$ respectively. The major fatty acid of the alga was oleic acid irrespective of light changes. The quantities of lipid accumulated and the properties of the fatty acid methyl esters showed that Desmodesmus subspicatus LC172266 is an ideal feedstock for biodiesel production.
\end{abstract}

Keywords: Desmodesmus subspicatus, light intensities, biodiesel, lipid productivity, photoperiods, microalgae

\section{Introduction}

The last few decades have witnessed an increased interest in microalgal research especially with regards to their application as an important bioresource in the production of greener and renewable fuels. So, the idea of developing microalgae as a source of biofuels is not a new concept (McGuin et al., 2011). With the controversies and complexities surrounding $1^{\text {st }}$ and $2^{\text {nd }}$ generation biofuels, in addition to the finite nature of fossil fuels and the attendant environmental issues arising from their very usage, microalgae have been viewed and researched as viable and sustainable alternative. The reduction of the emission of greenhouse gasses and consequently contributing significantly to mitigating global warming and the concomitant climate change is one of the key advantage of microalgae (Darzins et al., 2010). Compared to the terrestrial plants, these microorganisms have more $\mathrm{CO}_{2}$ use efficiency, sequestering $\mathrm{CO}_{2}$ to make biomass with better efficiency than terrestrial plants and some have $50 \%$ of 
their dry cell weight as lipid (Darzins et al., 2010).

The selection of oleaginous, high lipid-containing microalgal strains for biodiesel production is focused not only on lipid content but also on growth conditions (Han et al., 2015). A wide range of factors including temperature, $\mathrm{CO}_{2}$, available nutrients, light and salinity influence the growth and by extension microalgal lipid accumulation. However, to a very large extent, light is considered the strongest factor affecting growth and storage products of microalgae (Han et al., 2015) and hence, has been studied as it affects the growth of various microalgae. For example, Scott et al. (2010) obtained low biomass with low light intensity (LI) and photoinhibition with high LI. This situation was previously described by Campbell et al. (1995) and alluded to by McGuin et al. (2011). However, Han et al. (2015) inferred that under most incubation conditions, especially with relatively high cell concentration, the light is limited without photoinhibition. Ruangsomboon (2012) observed that the microalga Botryococcus braunii had the highest lipid yield of $0.45 \mathrm{~g}$ $\mathrm{L}^{-1}$ as the intensity of the tested light was increased from 0.3 to its highest $538 \mu \mathrm{E} \mathrm{m}^{-}$ ${ }^{2} \mathrm{~s}^{-1}$. The findings further suggested that a relatively high light intensity limited algal growth, but favored an increase in the content and yield of the lipids (Han et al. 2015).

Light intensity affects lipid yields in microalgae which in turn is of particular interest in algal biodiesel production (Nzayisenga et al., 2020). Increasing light intensity has been reported to reduce lipid production in some microalgae (Cheirsilp and Torpee 2012), but enhancing lipid biosynthesis in some other species and additionally may have no effect on some other species (Pancha et al., 2015; Seo et al., 2017). Therefore, Nzayisenga et al. (2020) recommended that studying the effect of light intensity on lipid production should be done on a species-by-species basis.

The present study investigated the influence of the light intensity and photoperiod on the growth and lipid accumulation of Desmodesmus subspicatus
LC172266. The microalga was isolated locally and characterized morphologically and by molecular approaches as reported below. Effects of light intensity and light: dark cycles on biomass production and lipid accumulation were investigated. Fatty acid composition of the algal lipid extracted from growth under optimal and un-optimized light conditions were determined by gas chromatography-mass spectrometry. Biodiesel property analysis was deduced using a BiodieselAnalyzer software and compared to ASTM and EN standards.

\section{Materials and Methods The Microalga Desmodesmus}

subspicatus

LC172266 was isolated from wastewater in Maiduguri, North-East Nigeria (Ogbonna, 2014) and was identified using both morphological and molecular approaches (Ogbonna and Ogbonna, 2015; Eze et al., 2017).

\section{Effects of light intensity on biomass production and lipid accumulation}

The influence of light intensity on the growth and lipid accumulation by the alga was determined by cultivating the microalga at different light intensities: 0 , $1000,2000,3500$ and $5000 \mathrm{~lx}$, and measuring the growth and lipid biosynthesis. The alga was cultivated in $2000 \mathrm{~mL}$ transparent Teflon bottles containing 1000 $\mathrm{mL}$ of a sterile BG-11 medium (Ogbonna and Ogbonna, 2015). Dilute hydrochloric acid and sodium hydroxide solutions were used to equilibrate the initial medium $\mathrm{pH}$ to 7.3 before the autoclave-sterilization. The inoculation of each bottle was done by adding $15 \%(\mathrm{v} / \mathrm{v})$ of a week's old seed culture of Desmodesmus subspicatus LC172266. The culture vessels capped with quality urethane foam were incubated at room temperature of $30 \pm 2{ }^{\circ} \mathrm{C}$ for 12 days (Ogbonna and Ogbonna, 2015) and the carbon source was atmospheric carbon IV oxide $\left(\mathrm{CO}_{2}\right)$ allowed to diffuse into the culture through quality foam plugging. The cultures were illuminated using four pieces of 2-feet white fluorescent tubes arranged in parallel and light intensity variation (with intensities $0 \sim 5000 \mathrm{~lx}$ ) were achieved by distance adjustment of the light and incubation in the dark. The duration of light 
exposure was $12 \mathrm{~h}$ followed by $12 \mathrm{~h}$ darkness every day. Prior to choosing the range of light intensities, an initial measurement of the LI of the natural environment of the growing alga was made. Light intensity measurement (using light meter, LX-1000, Japan) of the culture medium was done at centre of the culture bottle. Each day, the cultivated algal culture was agitated two times by shaking at 120 revolutions per minute (rpm) for $10 \mathrm{~min}$ in an orbital shaker (Gallenkamp Ltd, United Kingdom). Biomass, chlorophyll and oil contents were analyzed every two days using $10 \mathrm{~mL}$ of the algal culture broth for each determination. For each set-up, there were 3-replicates and the mean and standard error of means were deduced.

\section{Influence of light: dark cycles on biomass yield and lipid accumulation}

Optimal light: dark cycle for biomass yield and biosynthesis of lipids was assessed by culturing Desmodesmus subspicatus LC172266 at light: dark timings of 12:12, 14:10, 16:08 and 18:06 $\mathrm{h}$ and testing for biomass, lipid and chlorophyll contents. The cultivation conditions were as reported for LI above. However, cultures were illuminated using 2-feet white fluorescent tubes arranged in parallel with an LI of $5000 \mathrm{Ix}$ only. Other culture variables not mentioned, sample collection and analyses were as described above for light intensity.

Effects of optimal and un-optimal light intensity and light: dark cycles on lipid composition

Effects of optimal and un-optimal light intensity and light: dark cycles on lipid composition were demonstrated. For optimal cultivation, Desmodesmus subspicatus LC172266 was grown at light: dark timings of 18:06 $\mathrm{h}$ and a light intensity of $3500 \mathrm{Ix}$ for eight days. The cultivation at un-optimal light regime was done at a photoperiod of 12:12 h per day and light intensity of 1000 $\mathrm{Ix}$ for eight days. Other cultivation conditions remained constant as reported above. Cultures were harvested on the eightieth day of incubation, followed by the extraction of lipid by a protocol reported below. Lipid composition was measured using the GC-MS protocol described below.
Determination of biomass concentrations

Biomass concentration was determined as cell dry weight every $48 \mathrm{~h}$ up to stationary phase.

Algal biomass productivity was measured as $\mathrm{gL}^{-1}$ day $^{-1}$ as in Okpozu et al. (2019) (Equation 1).

Biomass productivity, $P_{B},\left(g L^{-1}\right.$ day $\left.^{-1}\right)=$ $\frac{C_{B}-C_{A}}{t} \quad$ Equation 1. where, $C_{A}\left(g L^{-1}\right)$ is the initial biomass concentration, $C_{B}\left(g L^{-1}\right)$, cell dry weight at a time $(t)$ of the batch culture.

The dry cell weight of the Desmodesmus subspicatus LC172266 was obtained by centrifuging ten milliliters of the broth culture at $3000 \times \mathrm{g}$ for $15 \mathrm{~min}$. The cell pellets were washed consecutively for three times using sterile distilled water. This was thereafter transferred into a Whatman No. 1 filter paper of known weight and tagged $\mathrm{w}_{1}$. The biomass extract was dried in a hot air oven at $70^{\circ} \mathrm{C}$ for $7 \mathrm{~h}$ until a constant weight was achieved. This was desiccated for $5 \mathrm{~h}$ before getting the weight $2\left(w_{2}\right)$. To obtain cell dry weight, Liang et al. (2005) equation was adapted as in equation 2 .

Cell Dry Weight $(C D W)=W_{2}-W_{1}$,

$C D W\left(g L^{-1}\right)=\frac{W_{2}-W_{1}}{V} \times \frac{1000}{1}$

(Equation 2)

where, $\mathrm{w}_{2}=$ weight of filter paper and dried algal mass $(g), w_{1}=$ weight of the filter paper $(\mathrm{g})$ and $\mathrm{v}=$ volume of broth $(\mathrm{mL})$.

\section{Chlorophyll contents estimation}

To determine the chlorophyll quantity in the culture, we used water and absolute methanol as extractants and Becker (1994)'s documented protocol was adapted. Tenmilliliter quantities of the algal broth were harvested with the washing as reported above for cell dry weight. Chlorophyll was extracted from the cell pellets by adding 3 $\mathrm{mL}$ methanol and boiling in a water bath for $5 \mathrm{~min}$. The contents of the boiled chlorophyll extract were cooled and made up to $5 \mathrm{~mL}$ volumes using methanol and measured in a spectrophotometer (Spectrumlab 22) at different wavelengths against the solvent blank. Chlorophyll contents calculations 
were as shown in Equations 3 (Becker, 1994).

Chlorophyll $a+b\left(\mathrm{mg} \mathrm{L}^{-1}\right)=$

$\left(4.0 \times \mathrm{A}_{665}\right)+\left(225.5 \times \mathrm{A}_{650}\right)$

(Equation 3)

The chlorophyll contents in the algal biomasses ( $\mathrm{mg} \mathrm{g}^{-1}$ biomass) were calculated by dividing the concentration of the chlorophylls ( $\mathrm{mg} \mathrm{L}^{-1}$ ) by the cell dry weight (Cheirsilp and Torpee 2012).

Determination of lipid content

Lipid content was determined using a protocol adapted from two-step Bligh and Dyer (1959). The solvent system was water, methanol and chloroform. To a sample containing $1 \mathrm{ml}$ water, $3.75 \mathrm{ml}$ of a mixture chloroform/methanol (1/2) was added and vortex mixed for $10-15 \mathrm{~min}$. Then $1.25 \mathrm{ml}$ chloroform was added with mixing for $1 \mathrm{~min}$ and $1.25 \mathrm{ml}$ water with mixing another minute before centrifugation. Using this means, lipid was extracted and transferred to a vial of known weight. The chloroform was evaporated in a water bath set at $55^{\circ} \mathrm{C}$ with a steady flow of $\mathrm{N}_{2}$ gas. The sample was thereafter dried in an oven at $105^{\circ} \mathrm{C}$ for $1 \mathrm{~h}$ and the vial weighed again and the extracted lipid content expressed as percentage lipid. The LP was expressed in $g L^{-1}$ day $^{-1}$ as in Equation 4 (Griffiths and Harrison, 2009).

Lipid productivity, $L P,\left(g L^{-1} d a y^{-1}\right)=$ Total microalgae biomass production $(g) \times$ lipid content $(\%)$ working volume $(l) \times$ cultivation time (Equation 4)

\section{Determination of fatty acid composition}

The fatty acid composition of Desmodesmus subspicatus LC172266 lipid was determined by gas chromatographymass spectrometry (GC-MS-QP2010 PLUS Shimadzu, Japan) using a micro-bore capillary column (Db 30.0). Helium was the gas carrier (flow rate was $1.8 \mathrm{~mL} \mathrm{~min}^{-1}$ ). The oven temperature was $70{ }^{\circ} \mathrm{C}$, injection temperature, $250{ }^{\circ} \mathrm{C}$ with split injection

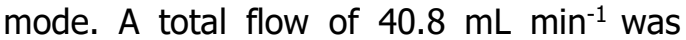
recorded and MS table start time of 3.00 $\mathrm{min}$, and retention time of $24.00 \mathrm{~min}$ were also recorded. The fatty acids were identified from the chromatograms by comparing the spectrum of the unknown component with the spectrum of the known components stored in the National Institute of Standards and Technology (NIST) library. The retention time, the spectra and the molecular name, molecular weight and formula were used as identification parameters. The properties of the fatty acid methyl ester (biodiesel) was measured by means of a BiodieselAnalyzer software (Talebi et al., 2014).

\section{Statistical analyses of the data}

Data were analyzed by One-way ANOVA using STATGRAPHICS Centurion XVI Version 16.1.05 $(P<0.05)$.

\section{Results and Discussion}

Influence of light intensity on the growth and lipid accumulation by Desmodesmus subspicatus LC172266

Light intensity significantly influences algal growth and accumulation of lipids to such an extent that when the nutrients are not limited, the growth of microalgae depend on the light conditions (Han et al., 2015). Growth of Desmodesmus subspicatus LC172266 was promoted by light intensity (LI) in an increasing order of $1000,2000,3500$ and $5000 \mathrm{~lx}$ (Fig. 1). Light intensity tolerance of up to $300 \mu \mathrm{Em}^{-2} \mathrm{~s}^{-1}$ has also been documented for another Desmodesmus sp (Nzayisenga et al., 2020). However, in the present study, increasing LI beyond $5000 \mathrm{~lx}$ to $10000 \mathrm{~lx}$ and above (for between $24 \sim 48 \mathrm{~h}$ ) led to the bleaching of the culture broth and consequent destruction of the microorganism (result not shown since it was clear the cells were dead). This could imply that there was a photo-inhibition at high irradiance. The apparent photo-inhibition phenomenon observed in this study by very high light irradiation had previously been described by Subramaniam et al. (2010) for a related species of microalga.

At the other end of the scale (in the present study), incubation of the alga in the dark $(0 \mathrm{Ix})$ resulted in some instances of very low biomass but in most cases a total cessation of growth. This is not surprising since $D$. subspicatus is a freshwater green microalga requiring light for its food 
manufacture implying that incubation in the dark may have affected a key process in the metabolism of the alga. Similarly, in this culture incubated in the dark $(0 \mathrm{Ix})$, LP was not determined due to insufficient biomass to run a lipid content assay (Table 1). Here, the yield was very low and values almost stationary from the beginning of the study to the end, resulting in the inability to run the lipid content or productivity test.

Although the cultures irradiated with LI $5000 \mathrm{Ix}$ had numerically more cell mass, the 3500-lx showed higher lipid productivity. This could be because lipid productivity is a dual function of the biomass productivity and the lipid content. Therefore, even though the cell biomass may numerically be higher, the lipid productivity may not since the biomass content, the lipid content and the working volume are all taken into account in deducing lipid productivity (Griffith and Harrison, 2009). Ruangsomboon (2012) had previously obtained an equivalence of $5000 \mathrm{~lx}$ for optimal growth of Botrycoccus braunii KMITL 2 whereas Cheirsilp and Torpee (2012) reported the range of $2000 \sim 8000 \mathrm{~lx}$ for optimal growth and oil accumulation by two related species of microalgae. In all cases of the present investigation, the peak biomass concentrations were obtained on the day eight of the cultivation (Table 1) implying that maximal biomass harvesting needs to be targeted towards the eightieth day of incubation for this particular microalga under the studied cultivation condition.

In this study of the influence of light intensity, although the highest lipid content was achieved at 1000 Ix (Fig. 2), lipid productivity (LP) was maximum (77.50 \pm $1.23 \mathrm{mg} \mathrm{L}^{-1} \mathrm{day}^{-1}$ ) when the incubation LI was 3500 Ix. This could have resulted because the low light intensity of $1000 \mathrm{~lx}$ that supported the highest lipid content did not support maximal algal biomass accumulation which is an integral component of lipid productivity. Therefore, 3500 Ix could be regarded as the optimal condition for better lipid accumulation of Desmodesmus subspicatus. This deduction was made because the overall attribute of a biological feedstock needed for biodiesel production centres around lipid productivity and lipid class. It was not entirely clear why highest lipid content and lipid productivity (LP) were not obtained at the same light intensity as previous in findings (Ruangsomboon, 2012) showed that algae grown at high light intensities often accumulated more lipids. Even with a Desmodesmus sp, Nzayisenga et al. (2020), had noted that a high light intensity of 300 $\mu \mathrm{Em}^{-2} \mathrm{~s}^{-1}$ supported higher fatty acid content. Krzeminska et al. (2015) suggested that increases in lipid content during condition of high light intensity could partly be caused by starvation. That could be true for the present study because at day 8 , lipid production was maximal when nutrient was presumably minimal. Nevertheless, in some other studies (Cheirsilp and Torpee, 2012; George et al., 2014), high light intensities led to reduction of the lipid in the cultures of Chlorella and Nannochloropsis spp., even though their biomass contents increased. Similarly, Nzayisenga et al. (2014) obtained a reduction in lipid contents of Chlorella vulgaris and Ettlia pseudoalveolaris cultivated at LI $300 \mu \mathrm{E} \mathrm{m} \mathrm{m}^{-2} \mathrm{~s}^{-1}$ and higher biomass than in cultures with lower LI. 


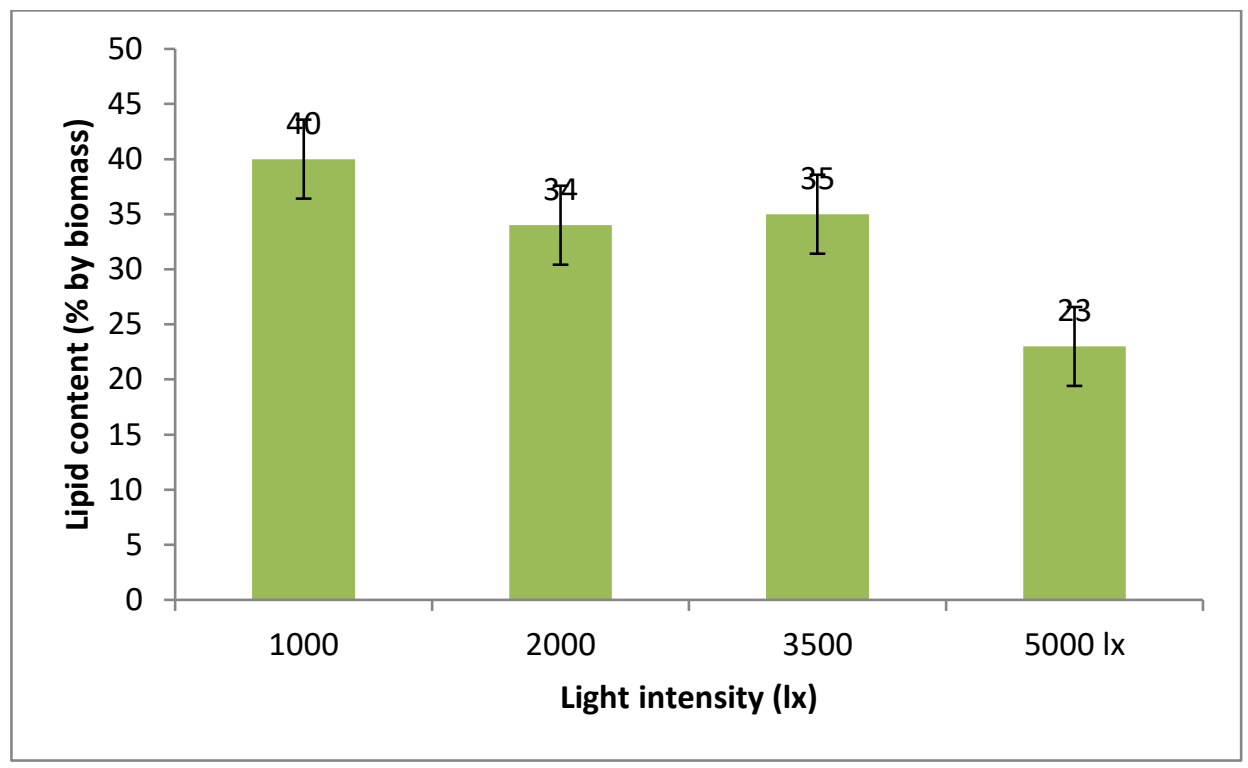

Fig. 2: Lipid accumulation by Desmodesmus subspicatus LC172266 under different Light intensity.

No statistical differences $(P>0.05)$ were observed with LI of 3500 and $5000 \mathrm{~lx}$ in terms of the biomass concentration. Chlorophyll content increased with LI with the highest $\left(20.40 \pm 0.50 \mathrm{mg} \mathrm{g}^{-1}\right.$ cell $)$ and lowest $\left(11.20 \pm 1.02 \mathrm{mg} \mathrm{g}^{-1}\right.$ cell) at $5000 \mathrm{~lx}$ and $1000 \mathrm{Ix}$ respectively (Table 1 ). Although, the opposite had previously been reported by Neidhardt et al. (1998) when Dunaliella salina cells grown under high-light exhibited lower chlorophyll levels than those grown under low-light, with the lower chlorophyll content attributed to irradiance stress (Srirangan et al., 2015). Therefore, it is not certain whether the current observation is species dependent or other unforeseen intrinsic or extrinsic factor.

Effects of light: dark cycles (LDC) on the growth and lipid accumulations (LA) by Desmodesmus subspicatus LC172266

The extent of exposure of the alga to light/dark regimes investigated showed that the growth and lipid elaboration by the alga were affected by the extent of the photoperiods. The optimal LDC for Desmodesmus subspicatus LC172266 growth and LA were 18:06 h (Fig. 3). This was followed by $16: 08 \mathrm{~h} \mathrm{LDC}$ and so on with decreasing influence, and with LDC of 12:12 $\mathrm{h}$ supporting the least algal growth irrespective of the LI. This is consistent with the findings of Ruangsomboon (2012) that light: dark cycle of $12: 12 \mathrm{~h}$ produced the least biomass of a green microalga Botryococcus braunii KMITL 2. The peak algal cell concentrations were reached on day 8 of cultivation by all the light treatment cycles and the lag phases were very short and almost un-detectable in all cases. Light exposure time is a direct factor for lipid production (Kato et al., 2019), hence, lipid accumulation correlated directly with the lengths of the light phases. Therefore, the highest lipid content (53\%) was obtained at 18: 06 LDC followed by $42 \%$ obtained in 16:08 h cycle (Fig. 4).

The lipid contents at 14:10 h, 16:08 $h$ and 18:06 $\mathrm{h}$ photoperiods were statistically different $(p<0.05)$ and the ones at photoperiod 12:12 $\mathrm{h}$ were significantly lower $(P<0.05)$ compared to the rest. This result contrasted with the findings of Anjala et al. (2015) when they reported a significantly higher percentage lipid content of $12.96 \%$ when Nannochloropsis sp. was grown at photoperiod 12: $12 \mathrm{~h}$ compared to $12.36 \%$ increase when grown at 16:8 LDC. The lipid content results did not support the results obtained by Ruangsomboon (2012) and a more recent report by Ma et al. (2017) for light: dark cycles. This could be because whereas, Ruangsomboon worked on a green 
microalga Botryococcus braunii KMITL 2, the present study investigated $D$. subspicatus LC172266.

Chlorophyll content was highest $(20.40 \pm$ $0.50 \mathrm{mg} \mathrm{g}^{-1}$ cell) and lowest $(14.91 \pm 1.32$ $\mathrm{mg} \mathrm{g}^{-1}$ cell) at LDC of 12:12 $\mathrm{h}$ and 18:06 h respectively using the $5000 \mathrm{Ix}$ (Table 2 ). This could imply that the longer the exposure of the organism to light, the smaller the chlorophyll yields. This could also be attributed to irradiance stress previously reported by Srirangan et al. (2015). The highest LP (118.80 $\pm 2.04 \mathrm{mg} \mathrm{L}^{-1}$ day $\left.^{-1}\right)$ was achieved at photoperiod $18 \mathrm{~h}$ per day. Biomass productivity (BP) was directly proportional to the lengths of light phases with the highest BP $\left(0.32 \pm 0.06 \mathrm{gL}^{-1} \mathrm{day}^{-1}\right)$ obtained at 18:06 $\mathrm{h}$ LDC cultures as observed by Anjala et al. (2015).

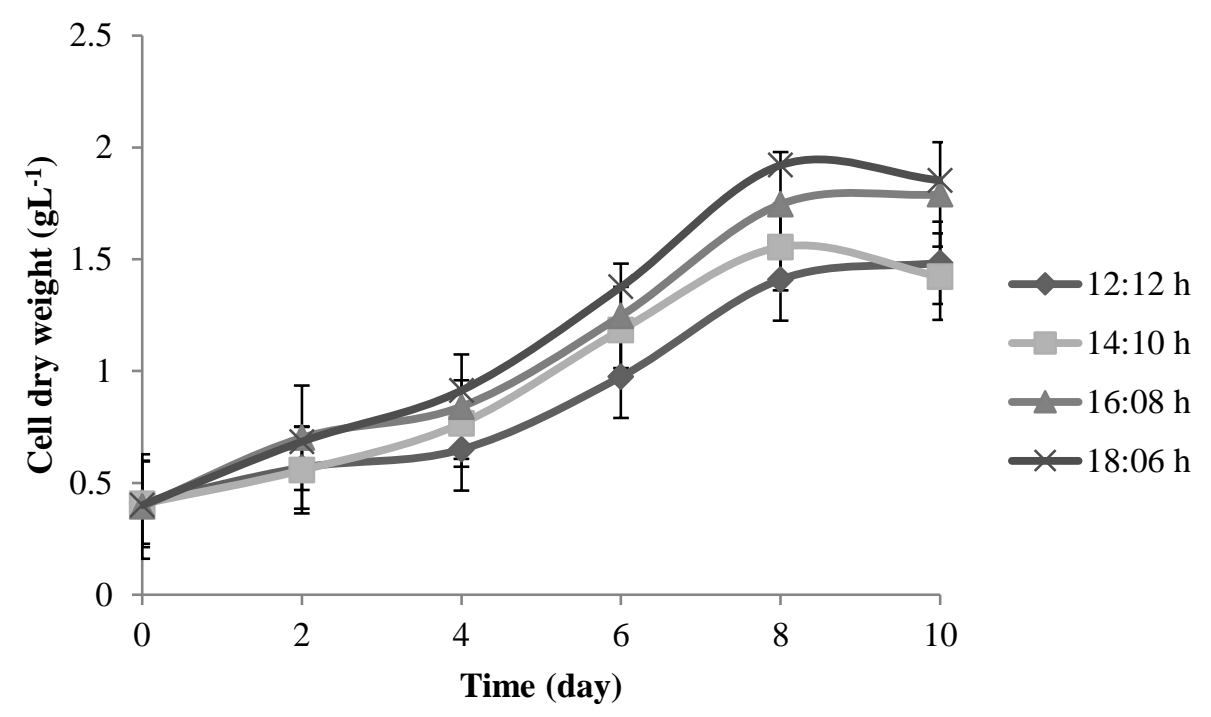

Fig. 3: Growth of Desmodesmus subspicatus under different light: dark cycles

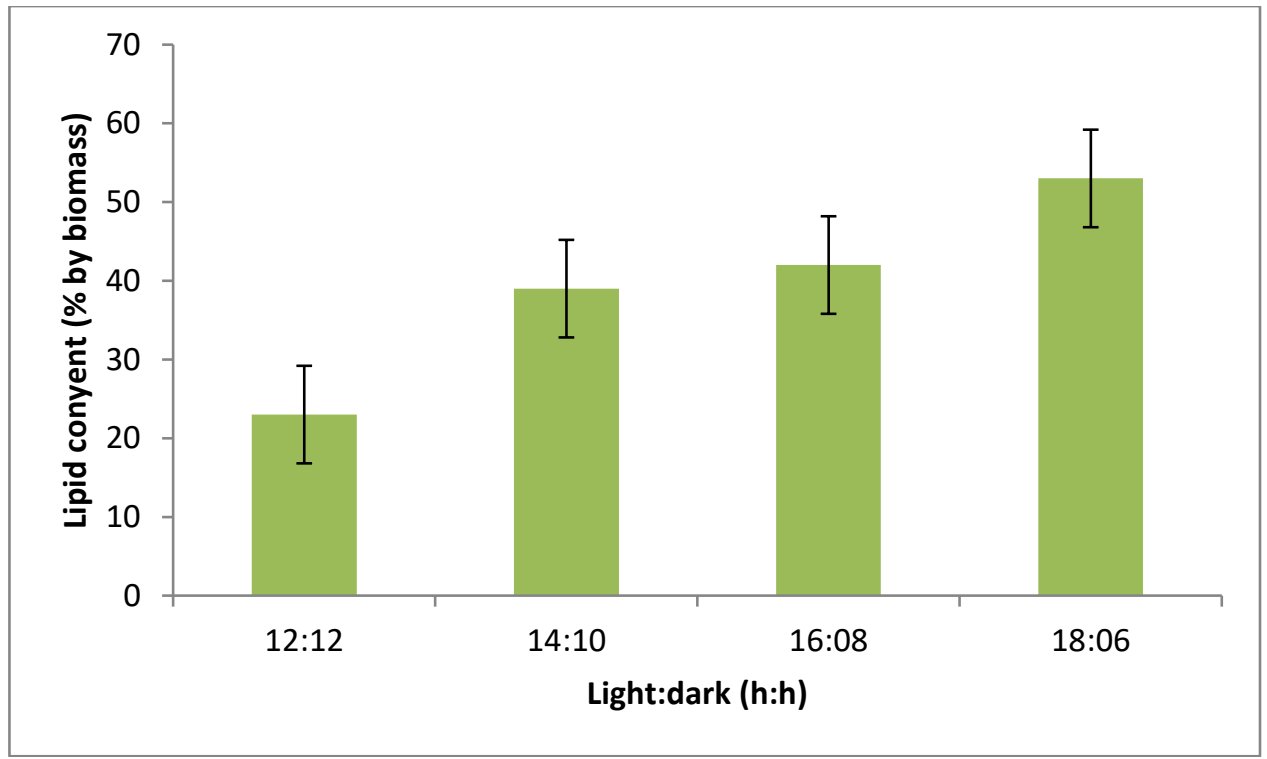

Fig. 4: Lipid accumulation by Desmodesmus subspicatus LC172266 under different light: dark cycles. 
Fatty acid composition

The major fatty acid compositions of Desmodesmus subspicatus LC172266 lipid under un-optimized and optimized light intensities and photoperiods are presented in Table 3. The major fatty acids eluted (shown by \% area of the peak of the fatty acid) under un-optimized conditions of light intensity and photoperiods were oleic acid (62.76), stearic acid methyl ester (7.96) and methyl 14-methyl-pentadecanoate (10.94) (Table 3). There were however, other minor fatty acids.

Similarly, under optimal conditions, the major fatty acids eluted were oleic acid (61.43), stearic acid methyl ester (9.69) and methyl 14-methyl-pentadecanoate (12.05) (Table 3).

There was no statistical difference between the fatty acid composition of the alga irrespective of the light intensity / photoperiod manipulation in culture conditions named optimized and unoptimized culture conditions. Solovchenko et al. (2008) noted that the higher the light intensity applied (from 35 to $400 \mu \mathrm{E} \mathrm{m}^{-2} \mathrm{~s}^{-1}$ ), the higher the fatty acid and arachidonic acid content in the cells of a related microalga Parietochloris incisa, implying that it was in contrast with the results of the present study. The difference could be attributed to the differences in the algal species used.

Table 2: Chlorophyll content, biomass and lipid production of microalga Desmodesmus subspicatus under different light: dark regimes.

\begin{tabular}{lllll}
\hline $\begin{array}{l}\text { Light dark } \\
\text { cycle }(\mathrm{h})\end{array}$ & $\begin{array}{l}\text { Max. Chlorophyll a } \\
+\mathrm{b}\left(\mathrm{mg} \mathrm{g}^{-1} \text { cell }\right)\end{array}$ & $\begin{array}{l}\text { Max. Biomass } \\
\text { concentration } \\
\left(\mathrm{g} \mathrm{L}^{-1}\right)\end{array}$ & $\begin{array}{l}\text { Biomass } \\
\text { productivity } \\
\left(\mathrm{g} \mathrm{L}^{-1} \text { day }^{-1}\right)\end{array}$ & $\begin{array}{l}\text { Lipid productivity }(\mathrm{mg} \\
\left.\mathrm{L}^{-1} \mathrm{day}^{-1}\right)\end{array}$ \\
\hline $12: 12$ & $20.40 \pm 0.50^{\mathrm{a}}$ & $1.60 \pm 0.24$ & $0.27 \pm 0.01^{\mathrm{c}}$ & $67.50 \pm 2.03^{\mathrm{d}}$ \\
$14: 10$ & $15.65 \pm 1.26^{\mathrm{b}}$ & $1.55 \pm 0.09$ & $0.26 \pm 0.02^{\mathrm{c}}$ & $82.50 \pm 1.45^{\mathrm{c}}$ \\
$16: 08$ & $20.02 \pm 0.94^{\mathrm{a}}$ & $1.79 \pm 0.01$ & $0.29 \pm 0.03^{\mathrm{b}}$ & $95.00 \pm 2.17^{\mathrm{b}}$ \\
$18: 06$ & $14.91 \pm 1.32^{\mathrm{c}}$ & $1.92 \pm 0.03$ & $0.32 \pm 0.06^{\mathrm{a}}$ & $118.80 \pm 2.04^{\mathrm{a}}$
\end{tabular}

Results $=$ means \pm SEM. Means that share different letters along the column are significantly different at 95\% confidence limit. $\mathrm{F}$ (Chlorophyll content) $=804.61, P=0.000(P<0.05)$ (Significant differences exist in chlorophyll content under different light dark cycle). $F($ Biomass productivity) $=31.26$, $\mathrm{P}=0.003(\mathrm{P}<0.05)$ (Significant differences exist in biomass productivity under different light dark cycle). $\mathrm{F}$ (Lipid productivity) $=1198.89, \mathrm{P}=0.000$ $(P<0.05)$ (Significant differences exist in lipid productivity under different light dark cycle).

Table 3: Major fatty acid composition of Desmodesmus subspicatus LC172266 under optimal and un-optimized light intensity and photoperiod

\begin{tabular}{|c|c|c|c|c|c|}
\hline $\begin{array}{l}\text { Retention } \\
\text { Time (min.) }\end{array}$ & $\begin{array}{l}\text { Name of } \\
\text { compound }\end{array}$ & $\begin{array}{l}\text { Molecular } \\
\text { Weight }\end{array}$ & $\begin{array}{l}\text { Molecular } \\
\text { Formula }\end{array}$ & $\begin{array}{l}\text { Abundance } \\
\text { (\%) optimal }\end{array}$ & $\begin{array}{l}\text { Abundance } \\
\begin{array}{l}\text { (\%) un- } \\
\text { optimal }\end{array}\end{array}$ \\
\hline 15.497 & $\begin{array}{l}\text { Methyl 14-methyl- } \\
\text { pentadecanoate }\end{array}$ & 270 & $\mathrm{C}_{17} \mathrm{H}_{34} \mathrm{O}_{2}$ & 12.05 & 10.94 \\
\hline 16.067 & Hexadecenoic acid & 256 & $\mathrm{C}_{16} \mathrm{H}_{32} \mathrm{O}_{2}$ & 5.46 & 6.32 \\
\hline 17.435 & $\begin{array}{l}\text { Stearic acid methyl } \\
\text { ester }\end{array}$ & 298 & $\mathrm{C}_{19} \mathrm{H}_{38} \mathrm{O}_{2}$ & 9.69 & 7.96 \\
\hline 17.780 & Oleic acid & 282 & $\mathrm{C}_{18} \mathrm{H}_{34} \mathrm{O}_{2}$ & 61.43 & 62.76 \\
\hline 17.953 & Octadecanoic acid & 284 & $\mathrm{C}_{18} \mathrm{H}_{36} \mathrm{O}_{2}$ & 3.98 & 5.91 \\
\hline
\end{tabular}

$\mathrm{T}$ (Optimization types) $=0.02, \mathrm{P}=0.987$ (\% abundance was statistically the same under the optimal and un-optimized light intensity 
Biodiesel property of fatty acids obtained from Desmodesmus sp grown at optimal and un-optimal light conditions

Biodiesel quality of the fatty acids obtained from Desmodesmussp grown at optimal and un-optimal light is presented in Table 4. Monosaturated fatty acid (MUFA) (61.43 and $62.76 \%$ respectively) was the most abundant followed by saturated fatty acid (32.39 and $32.18 \%$ respectively). In a previous study by Solovchenok et al. (2015) Desmodesmus sp acclimated to grow at high $\mathrm{CO}_{2}$ level produced palmitic acid, oleic acid and $\mathrm{a}-$ linoleic acid as the predominant fatty acids. El Semary (2011) had earlier obtained palmitic and palmitoleic acid as the major fatty acids in the polyphasic description of Desmodesmus sp isolate with the potential of bioactive compounds production. More recently, Ogbonna et al. (2018), Okpozu et al. (2019), obtained Octadecenoic acid, methyl ester and oleic acids from Desmodesmus sp grown in cassava wastewater as the major fatty acids. Knothe
(2008) had previously recommended these class of fatty acids as suitable of use in biodiesel production.

In the present study, there was no significant difference between each of the test parameters of optimal and un-optimal conditions. This implies that changes in the light intensity and photoperiods did not change the fatty acid class and the biodiesel properties. Iodine value $\left(\mathrm{gI}_{2} / 100 \mathrm{~g}\right)$ and cetane value were within the ASTM and EN recommended limits for biodiesel as were kinematic viscosity $\left(\mathrm{mm}^{2} / \mathrm{s}\right)$, and density $\left(\mathrm{g} / \mathrm{cm}^{2}\right)$. This implies that the oil produced using Desmodesmus sp under the test condition as feedstock leads to a good quality biodiesel. Previous report had also shown that Desmodesmussp is an ideal feed stock for biodiesel production. For instance, Ogbonna et al. (2018), Okpozu et al. (2019), obtained values comparable with the present for other Desmodesmus sp grown in cassava wastewater.

Table 4: Comparison of biodiesel quality of Desmodesmus subspicatus under optimal and unoptimized light intensity and photoperiod

\begin{tabular}{|c|c|c|c|c|c|c|c|}
\hline $\begin{array}{l}\text { Biodiesel } \\
\text { properties }\end{array}$ & $\begin{array}{l}\text { Optimal } \\
\text { light }\end{array}$ & $\begin{array}{l}\text { un- } \\
\text { optimal }\end{array}$ & $\begin{array}{l}\text { ASTM } \\
\text { D6751 }\end{array}$ & $\begin{array}{l}\text { EN } \\
14214\end{array}$ & DSME & DAME & PME \\
\hline SFA & 32.39 & 32.18 & $\mathrm{~N}$ & $\mathrm{~N}$ & & & \\
\hline MUFA & 61.43 & 62.76 & $\mathrm{~N}$ & $\mathrm{~N}$ & & & \\
\hline PUFA & 6.20 & 5.35 & $\mathrm{~N}$ & $\mathrm{~N}$ & & & \\
\hline $\begin{array}{l}\text { Iodine } \\
\text { Value } \\
\left.\mathrm{I}_{2} / 100 \mathrm{~g}\right)\end{array}$ & 68.23 & 67.84 & $\mathrm{~N}$ & $\begin{array}{l}120.00 \\
(\max )\end{array}$ & 7.20 & 57.00 & 49.56 \\
\hline $\begin{array}{l}\text { Cetane } \\
\text { number }\end{array}$ & 58.15 & 58.17 & $\begin{array}{l}47.00 \\
(\min )\end{array}$ & $\begin{array}{l}51.00 \\
(\min )\end{array}$ & 91.10 & 75.00 & 61.00 \\
\hline $\begin{array}{l}\text { Long Chain } \\
\text { Saturated } \\
\text { Factor }\end{array}$ & 7.96 & 8.11 & $\mathrm{~N}$ & $\mathrm{~N}$ & 8.85 & 15.47 & - \\
\hline $\begin{array}{l}\text { Cold Filter } \\
\text { Plugging } \\
\text { Point }\left({ }^{\circ} \mathrm{C}\right)\end{array}$ & 8.53 & 8.99 & $\mathrm{~N}$ & $\begin{array}{l}\leq 5 / \leq- \\
20.00\end{array}$ & -8.30 & -12.50 & 13.00 \\
\hline $\begin{array}{l}\text { Kinematic } \\
\text { Viscosity } \\
\left(\mathrm{mm}^{2} / \mathrm{s}\right)\end{array}$ & 4.14 & 4.16 & $\begin{array}{l}1.90- \\
6.00\end{array}$ & $\begin{array}{l}3.50- \\
5.00\end{array}$ & 2.28 & 3.80 & 4.53 \\
\hline $\begin{array}{l}\text { Density } \\
\left(\mathrm{g} / \mathrm{cm}^{2}\right)\end{array}$ & 0.87 & 0.88 & $\mathrm{~N}$ & $\begin{array}{l}0.86- \\
0.90\end{array}$ & 0.49 & 0.65 & 0.87 \\
\hline
\end{tabular}




\section{Conclusion}

The biomass yield, lipid content and lipid productivity of Desmodesmus subspicatus were high, $1.92 \pm 0.03 \mathrm{~g} / \mathrm{L}, 53 \%$ and 118.80 $\pm 2.04 \mathrm{mgL}^{-1} \mathrm{day}^{-1}$ respectively, showing its potential applicability in biofuel biotechnology vis-à-vis the fatty acid methyl ester properties. Light utilization optimization did not change the major fatty acid which was composed mainly of MUFA and SFA, in addition, the biodiesel was of excellent quality.

\section{References}

Anjala, M. G., Chintha, P. R. and Siripala, S. (2015). Light Intensity and photoperiod effect on growth and lipid accumulation of microalgae Chlorella vulgaris and Nannochloropsis sp. for biodiesel production. Proceedings of $12^{\text {th }}$ ISERD International Conference, Tokyo, Japan, $26^{\text {th }}$ Sept. 2015, ISBN: 978-93-85832-00-0.

Arora, N. Patel, A. Sartaj, K.M. Pruthi, P.A. and Pruthi, V. (2016) Bioremediation of domestic and industrial wastewaters integrated with enhanced biodiesel production using novel oleaginous microalgae. Environmental Science and Pollution Research, 23(20): 20997-21007. DOI 10.1007/s11356-016-7320-y.

Becker, E. W. (1994). Microalgae: Biotechnology and Microbiology, Cambridge University Press, New York.

Bligh, E. G. and Dyer, W. J. (1959). A rapid method of total lipid extraction and purification. Canadian Journal of Biochemistry and Physiology, 37:911-17.

Briens, C., Piskorz, J. and Berruti, F. (2008). Biomass valorization for fuel and chemicals production - a review. International Journal of Chemical Reactor Engineering, 6:1-49.

Campbell, D., Zhou, G., Gustafsson, P., Oquist, G. and Clarke, A. K. (1995). Electron transport regulates exchange of two forms of photosystem II D1 protein in the Cyanobacterium synechococcus. EMBO Journal, 14:5457-66.

Cheirsilp, B. and Torpee, S. (2012). Enhanced growth and lipid production of microalgae under mixotrophic culture condition: Effect of Light intensity (LI), glucose concentration and fed-batch cultivation Bioresource Technology, 110:510-16.

Chisti, Y. (2007). Biodiesel from microalgae. Biotechnology Advances, 25(3):294-06.

Darzins, A. I., Pienkos, P. and Edye, L. (2010). Current status and potential for algal biofuels production: A report to IEA Bioenegy Task 39. Report T39-T2 6 August 2010 1-146.

El Semary, N. A. (2011). The polyphasic description of Desmondesmus spp. isolate with the potential of bioactive compounds production. Biotechnology, Agronomy and Society and Environment 15 (2): 231 - 238.

Eze, C. N., Ogbonna, J. C., Ogbonna, I. O. and Aoyagi, H. (2017). A novel flat plate airlift photobioreactor with inclined reflective broth circulation guide for improved biomass and lipid productivity by Desmodesmus subspicatus LC172266. Journal of Applied Phycology, 29(6):2745-54. DOI:10.1007/s10811-017-1153-z.

George, B., Pancha, I., Desai, C., Chokshi, K., Paliwal, C., Ghosh, T., Mishra, S. (2014). Effects of different media composition, light intensity and photoperiod on morphology and physiology of freshwater microalgae Ankistrodesmus falcatus - a potential strain for bio-fuel production. Bioresource Technology, 171:367-74.

Griffiths, J. M. and Harrison, T. L. (2009). Lipid productivity as a key characteristic for choosing algal species for biodiesel production. Journal of Applied Phycology, 21:493-507.

Han, S., Jin, W., Tu, R. and Wu, W. (2015). Biofuel production from microalgae as feedstock: current status and potential. Critical Reviews in Biotechnology, 35(2): 255-68.

Kato, Y., Fujihara, Y., Vavricka, C. J., Chang, J. S., Hasunuma, T. and Kondo, A. (2019). Light/dark cycling causes delayed lipid 
accumulation and increased photoperiodbased biomass yield by altering metabolic flux in oleaginous Chlamydomonas $s p$. Biotechnology for Biofuels, 12(39):1-11. https://doi.org/10.1186/s13068-019-1380$\underline{4}$.

Knothe, G. (2008). "Designer" biodiesel: optimizing fatty ester composition to improve fuel properties. Energ. Fuels. 22: 1358-1364.

Krzeminska, I., Piasecka, A., Nosalewick, A., Simionato, D., Wawrzykowski, J. (2015). Alterations of the lipid content and fatty acid profile Chlorella prothecoides under different light intensities. Bioresource Technology, 196: $72-77$

Liang, Y., Mai, K. and Sun, S. (2005). Differences in growth, total lipid content and fatty acid composition among 60 clones of Cylindrotheca fusiformis. Journal of Applied Phycology, 17:61-65.

Ma, C., Zhang, Y., Ho, S., Xing, D., Ren, N. and Liu, B. (2017). Cell growth and lipid accumulation of a microalgal mutant Scenedesmus sp. z-4 by combining light/dark cycle with temperature variation. Biotechnology for Biofuels, 19(260):1-13.

McGuin, P. J., Dickinson, K. E., Bhatti, S., Frigon, J., Guiot, S. R. and O'Leary, S. J. B. (2011). Integration of microalgae cultivation with industrial waste remediation for biofuel and bioenergy production: opportunities and limitations. Photosynthesis Research, 1-17. DOI 10.1007/s11120-011-9638-0.

Melis, A. (2009). Solar energy conversion efficiencies in photosynthesis: minimizing that chlorophyll antennae to maximize efficiency. Plant Science, 177:272-80.

Neidhardt, J., Benemann, J. R., Zhang, L. and Melis, A. (1998). Photosystem-II repair and chloroplast recovery from irradiance stress: relationship between chronic photoinhibition, light-harvesting chlorophyll antenna size and photosynthetic productivity in Dunaliella salina (green algae). Photosynthesis Research, 56(2):175-84.
Nzayisenga, J. C., Farge, X., Groll, S. L. and Sellstedt, A. (2020). Effects of light intensity on growth and lipid production in microalgae grown in wastewater. Biotechnology for Biofuels, 13(4):1-8. https://doi.org/10.1186/s13068-019-1646$\mathrm{x}$.

Ogbonna, I. O. (2014). Biodiesel production potentials of microalgae isolated from arid environments of Nigeria. (Doctoral thesis, Department of Microbiology, University of Nigeria, Nsukka, Nigeria).

Ogbonna, I. O., and Ogbonna, J. C. (2015). Isolation of microalgae species from arid environments of Northern Nigeria and evaluation of their potentials for biodiesel production. African Journal of Biotechnology, 14(18):1596-04.

Ogbonna, I. O., Okpozu, O. O., Ikwebe, J. and Ogbonna, J. C. (2018). Utilization of Desmodesmus subspicatns LC172266 for simultaneous remediation of cassava wastewater and accumulation of lipids for biodiesel production. Biofuels, 10(5):657-64. https://doi.org/10.1080/17597269.2018.14 $\underline{26164}$

Okpozu, O. O., Ogbonna, I. O., Ikwebe, J. and Ogbonna, J. C. (2019). Phycoremediation of cassava wastewater by Desmodesmus armatus and the concomitant accumulation of lipids for biodiesel production. Bioresource Technology Reports, 7:100255.

Pancha, I. Chokshi, K. Mishra, S. (2015). Enhanced biofuel production potential with nutritional stress amelioration through optimization of carbon source and light intensity in Scenedesmus sp CCNM 1077. Bioresource Technology 179: 565 - 572.

Ruangsomboon, S. (2012). Effect of light, nutrient, cultivation time and salinity on lipid production of newly isolated strain of the green microalga, Botryococcus braunii KMITL 2. Bioresource Technology, 109:261265.

Scott, S. A., Davey, M. P., Dennis, J. S., Horst, I., Howe, C. J., Lea-Smith, D. J. and Smith, A. G. (2010). Biodiesel from algae: 
challenges and prospects. Current Opinion in Biotechnology, 21:277-286.

Seo, S. H. Ha, J. S. Yoo, C. Srivastava, A. Ahn, C. Y. Cho, D. H. La, H. J. Han, M. S. Oh, H. M. (2017). Light intensity as a major factor to maximize biomass and lipid productivity of Ettlia $\mathrm{sp}$ in $\mathrm{CO}_{2}$-controlled photoautotrophic chemostat. Bioresource Technology 244: 621 - 628.

Sforza, E., Simionato, D., Giacometti, G. M., Bertucco, A. and Morosinotto, T. (2012). Adjusted light and dark cycles can optimize photosynthetic efficiency in algae growing in photobioreactors. PLoS One, 7(6):1-10. e38975.doi:10.1371/journal.pone.0038975.

Solovchenko, A. E., Khozin-Goldberg, I., Didi-Cohen, S., Cohen, Z., Merzlyak M.N. (2008). Effects of light intensity and nitrogen starvation on growth, total fatty acids and arachidonic acid in the green microalga Parietochloris incisa. Journal of Applied Phycology, 20:245-251.

Solovchenok, A. Gorelova, O. Selyakh, I. Pogosyan, S. Baulina, O Chivkunova, O. Voronova, E. Konyukhov, I. Scherbakov, P. Lobakova, E. (2015). A novel $\mathrm{CO}_{2}$-tolerant symbiotic Desmondesmus (Chlorophyceae, Desmondesmaceae): Acclimation to and performance at high carbon dioxide level. Algal Research, 11: $399-410$

Srirangan, S., Sauer, M. L., Howard, B., Dvora, M., Dums, J., Backman, P., Sederoff, $\mathrm{H}$. (2015). Interaction of Temperature and Photoperiod Increases Growth and Oil Content in the Marine Microalgae Dunaliella viridis. PLOS ONE, 10(5): e0127562. doi:10.1371/journal.pone.0127562.

Subramaniam, R., Dufreche, S., Zappi, M. and Bajpai, R. (2010). Microbial lipids from renewable resources: production and characterization. Journal of Industrial Microbiology and Biotechnology, 37:12711287.

Talebi AF, Tabatabaei M, Chisti, Y. (2014). BiodieselAnalyzer: a user-friendly software for predicting the properties of prospective biodiesel. Biofuel Res. J. 1(2): 55-57 (Available on http://www.brteam.ir/biodieselanalyzer). 